\title{
Microplastics in Freshwater Systems: A Review on Its Accumulation and Effects on Fishes
}

\author{
Asif Raza \\ Aligarh Muslim University, Department of chemistry, Aligarh U.P, INDIA \\ ABSTRACT: Plastic production is escalating tremendously throughout the globe and the reason \\ behind this is its durability and multipurpose utility. But there is a severe scarcity of its management. \\ Tonnes of plastics are dumped into water bodies across the world. These plastics breakdown \\ because of different reasons and results in the plastic debris of size $<5 \mathrm{~mm}$ termed as microplastics \\ (MPs) which are hazardous to aquatic life. They are a potential source of toxins as they offer a large \\ surface area to various chemicals present in the water body when these MPs are ingested by fishes it \\ causes serious health issues leading to mortality of the fishes. Therefore, we comprehensively \\ reviewed the sources of MPs in freshwater systems and its various types and how they get \\ accumulated inside the body of fishes. We found that fishes ingest these particles by mistaken for \\ food or accumulated these particles by consuming from lower trophic organisms. Some of the \\ commonly studied MPs are PE, PS, and PVC, examined from the body of fishes. MPs can cause \\ various ecotoxicological effects on fishes like behavioural change, cytotoxicity, neurotoxicity effects, \\ and liver stress etc. Our review study finds that there is a paucity of information on the accumulation \\ of MPs by freshwater fishes and there are very few studies on its effects also there is a debate \\ whether this accumulation is subjected to the bio-magnification process which ultimately affects \\ human life.
}

KEYWORDS: microplastics, sources, ecotoxicological, accumulation, freshwater

\section{INTRODUCTION}

Plastic materials are of vital use, being non-corrosive, durable, non-reactive, lightweight, easy to handle and its cheap manufacturing cost has made it a material of choice. Plastic production continues to accelerate and the reason behind this is the adoption of use and disposes of culture by almost all the developed and developing countries. Annual plastic production has increased from 1.5 million tonnes in the 1950s to 288 million tonnes in 2012 (PlasticsEurope, 2013) with only 9\% of plastics being currently recycled in the USA (EPA, 2014). The non-recycled plastic is being disposed off in dump yards, a major proportion of it is thrown as debris in the water bodies including oceans and rivers. It is estimated that $\mathbf{2 7 5}$ million metric tonnes of plastic waste is being generated each year (based on reports from 192 coastal countries, 2010). Due to a variety of physical, chemical and biological factors, these non-recycled plastics in the water bodies, breaks down to form microplastics (MPs). MPs from personal care products are one of the potential sources of direct addition to freshwater streams. Most of the studies have occurred in marine water systems but little data is available on the abundance and distribution of MPs in freshwater systems however MPs pollution is found in estuarine water and freshwater systems (Zhao et al., 2015; Su et al., 2016). Most studied impacts of plastic debris on biota are their physical effects such as entanglement, ingestion and suffocation/asphyxia (Barnes et al., 2009; Ryan et al., 2009; Sigler, 2014). These microplastics are often consumed by fishes via a variety of methods and cause adverse effects leading to mortality, 
neurotoxicity, cytotoxicity, liver stress, behavioural changes, oxidative stress, genotoxicity etc (Luis et al., 2018). Plastic abundance was found between the stomach, gut, and intestine of the fishes. The objective of this paper is to review the current knowledge of MPs contamination in freshwater and its effects on fishes. Summary of its occurrence and distribution is also discussed along with explored knowledge of its effects on fish health have been presented in this study. Several challenges have been discussed and suggestions are provided for further research work.

\section{MICROPLASTICS Overview- Types \& Sources:}

At first, the term 'microplastics' was used for the plastic matters in the range of $20 \mu \mathrm{m}$ (Thompson et al., 2004). But later, this range was widened in the range smaller than $5 \mathrm{~mm}$ (Arthur et al., 2009) and also the upper limit is $1 \mathrm{~mm}(1000 \mu \mathrm{m})$ stated by (Van Cauwenberghe et al., 2015). However, microplastics (MPs) are commonly defined as plastic particles having the size less than $5 \mathrm{~mm}$. (Betts, 2008; Fendall and Sewell, 2009; Hidalgo- Ruz et al., 2012). This study concerns primarily on the presence of MPs in freshwater bodies and its impacts on fishes. Research efforts on the accumulation and impacts in the freshwater system are very much less than the marine and terrestrial systems (Thompson et al., 2009; Wagner et al., 2014). The concentration of MPs is constantly increasing in the aquatic environment due to a tremendous increase in the production of plastics, with a total global production of 335 million tonnes in 2016 (Plastic Europe, 2017). Most of the authors have concluded that the primary sources of MPs are effluents from wastewater treatment plants (WWTPs), sewage sludge, shipping activities, atmospheric fallouts, direct disposal from the public, beach littering and run-offs from agricultural, recreational and urban areas. Although the data is so far unavailable, the runoffs from industrial plastic production sites can be taken as an additional source. The products such as facial scrubs have been identified as a potential source of MPs in water bodies. A study shows that the size range of four personal care and cosmetic product waste were in the range of 63-125 $\mu \mathrm{m}, 125-250 \mu \mathrm{m}, 250-500 \mu \mathrm{m}$, and 500-2000 $\mu \mathrm{m}$ (Browne, 2015). Generally, MPs are classified as primary or secondary on the basis of their production. Primary MPs are the ones having size $<5 \mathrm{~mm}$ and mainly are originated from textiles, medicines, toothpaste, and variety of other personal care products like facial and scrubs (Cole et al., 2011; Browne et al., 2015). The range of primary MPs and its types mainly consists of fragments (Rummel et al., 2016), fibres (Rummel et al., 2016), films and foams (Anderson et al., 2017). Secondary MPs can be originated by the fragmentation of big plastic materials degradation. They are derived from the degradation of larger plastic debris through mechanical forces, thermal degradation, photolysis, thermo-oxidation and bio-degradation processes (Zhao et al., 2015). For example synthetic fibres from washing clothes (Browne et al., 2011). Secondary MPs arising by washing clothes are generally polyester, acrylic, and polyamide which can be more than 100 fibres per litre of effluent (Habib et al., 1998; Browne et al., 2011). 


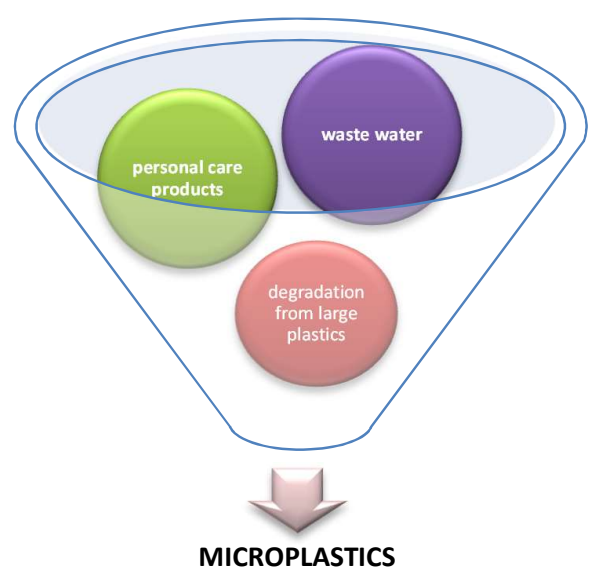

However, we also describe plastics according to their basic chemical structure as polyethylene (PE), polypropylene (PP), polyamide (PA), polyvinyl chloride (PVC), polystyrene (PS), polyurethane (PU), polyethylene terephthalate (PET) (Hidalgo-Ruz et al., 2012; Van cauwenberghe et al., 2015a). These are the structures extensively found in the majority of researches.

microplastic
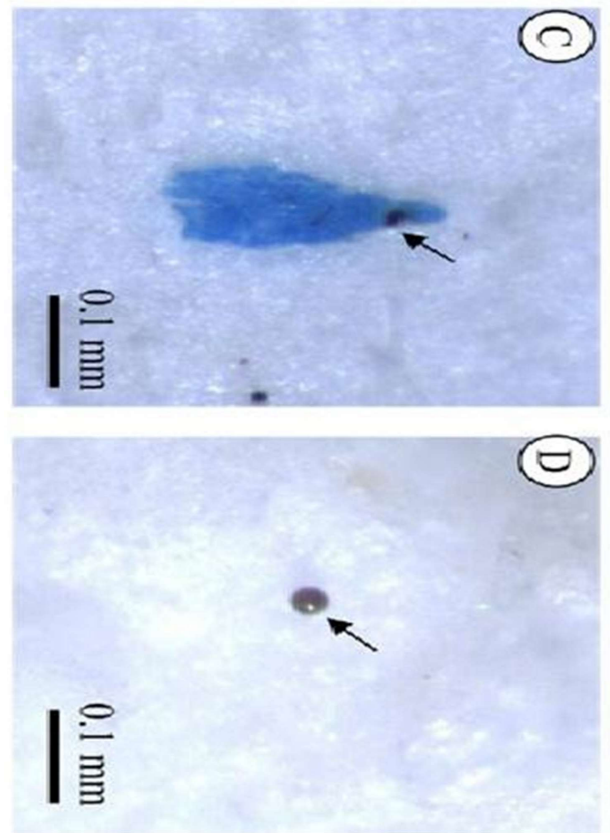

microplastic
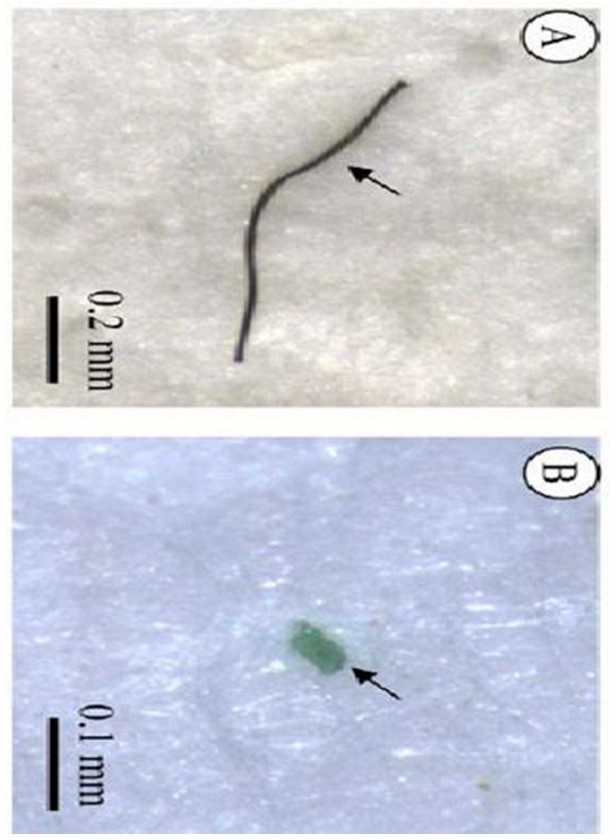

Fig: Photographs of microplastics from fish in China (Khalida et al., 2016). 


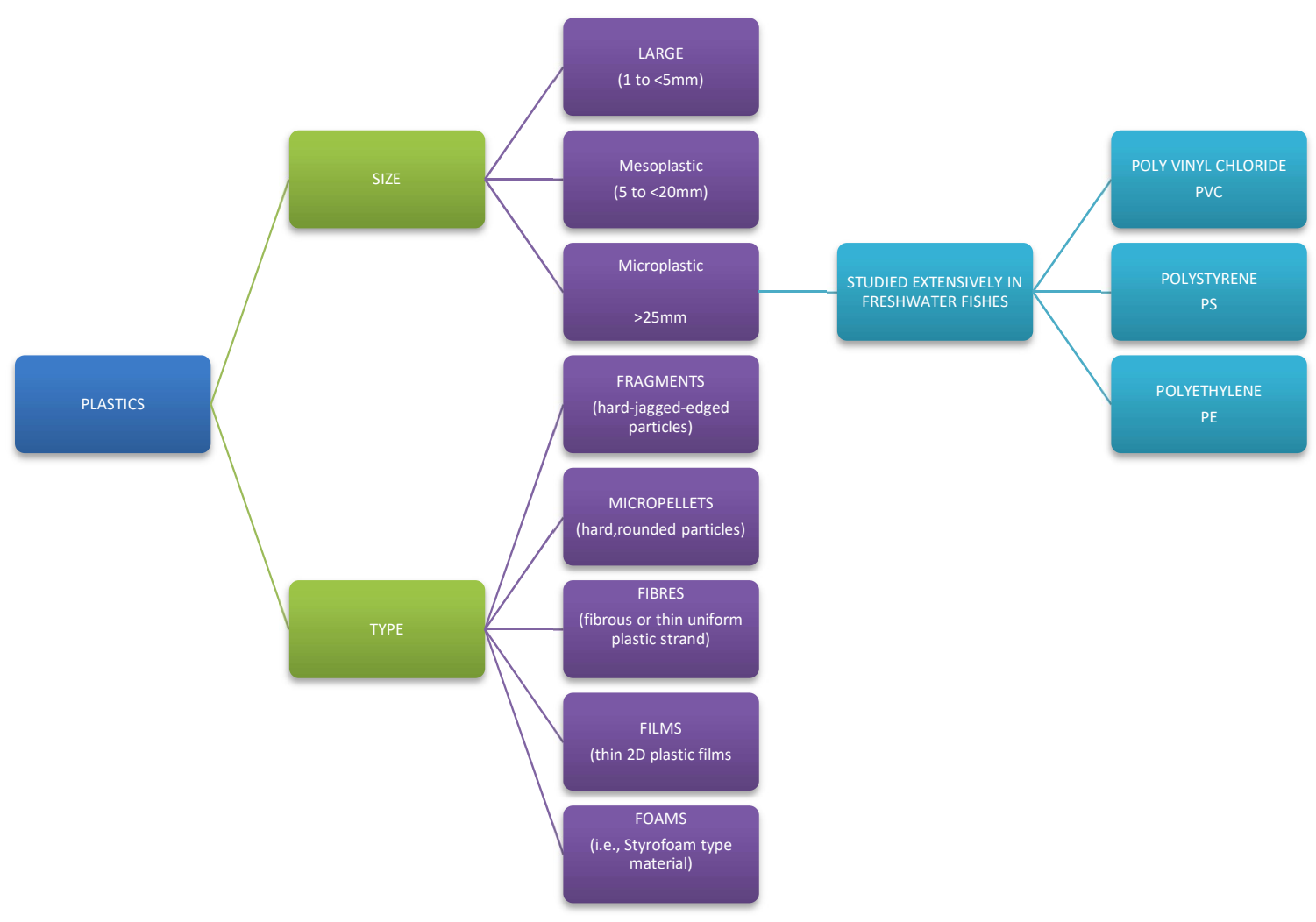

Fig 1; Flow-diagram of types of plastics information collected from (Lee et al., 2013; Anderson et al., 2017; Hidalgo-Ruz et al., 2015a).

\section{Methods of ingestion of MPs by fishes:}

Ingestion is one of the most common factors associated with plastic debris, have been reported by more than 270 taxa (Laist, 1997) from a variety of trophic level (Cole et al., 2011). One of the most affected taxa is fish. Plastic and other debris may be intentionally ingested by fish (Cole et al., 2011; Laist, 1997). Incidental ingestion happens with the ingestion of natural food items (Peters and Bratton, 2016), or through trophic transfer, when fish consumes prey that has already ingested plastic debris (Cedervall et al., 2012; Mattsson et al., 2015). On the other hand, intentional ingestion occurs when the plastic material is mistaken for food, especially bottom algae and fragment like foods (Ivar do Sul and Costa, 2007). Evidence suggests that intentional ingestion of plastic is most common in fish. For instance, marks left in large plastic debris suggest fish frequently attack and bite plastic items present in the environment (Carson, 2013), and laboratory experiments suggest fish larvae feed preferentially on plastic particles when exposed to both microplastics and natural food (L€onnstedt and Ekl€ov, 2016). The ingested MPs usually get accumulated inside the stomach, gut, intestinal lining of the fishes which we examine to observe whether the ingestion has happened.

TABLE-1: Plastic debris ingestion in fish from freshwater habitats (Rivers, Estuaries, and Lakes). The frequency indicates the percentage of individuals observed with the plastic debris inside the gut

\begin{tabular}{llll}
\hline ENVIRON & LOCATION & SPECIES & FREQ \\
MENT & & UENERENCE & \\
\hline
\end{tabular}




\begin{tabular}{|c|c|c|c|c|}
\hline & & & $\mathrm{CY} \%$ & \\
\hline Lake & Lake Victoria (Africa) & Lates niloticus & 20 & Biginagwa et al.,(2016) \\
\hline Lake & Lake Victoria (Africa) & Oreochromis.niloticus & 20 & Biginagwa et al.,(2016) \\
\hline Estuary & Goina Estuary(Brazil) & Cathorops spixi & 18 & Posatto et al., (2011) \\
\hline Estuary & Goina Estuary(Brazil) & Cathorops agassizzi & 33 & Posatto et al., (2011) \\
\hline Estuary & Goina Estuary(Brazil) & Sciades herzbergii & 18 & Posatto et al., (2011) \\
\hline Estuary & Goina Estuary(Brazil) & Stellifer brasiliensis & 6.9 & Dantas et al., (2012) \\
\hline Estuary & Goina Estuary(Brazil) & Stellifer stellifer & 9.2 & Dantas et al., (2012) \\
\hline Estuary & Goina Estuary(Brazil) & Eugeress brasilianus & 16.3 & Ramos et al., (2012) \\
\hline Estuary & Goina Estuary(Brazil) & $\begin{array}{l}\text { Eucinostomos } \\
\text { melanopterus }\end{array}$ & 9.2 & Ramos et al., (2012) \\
\hline Estuary & Goina Estuary(Brazil) & Diapterus rhombeus & 11.4 & Ramos et al., (2012) \\
\hline River & $\begin{array}{l}\text { Brazos River } \\
\text { Basin(US) }\end{array}$ & Leponis megalotis & 44 & $\begin{array}{l}\text { Peters and } \\
\text { Bratton(2016) }\end{array}$ \\
\hline River & $\begin{array}{l}\text { Brazos River } \\
\text { Basin(US) }\end{array}$ & Lepomis macrochirus & 45 & $\begin{array}{l}\text { Peters and } \\
\text { Bratton(2016) }\end{array}$ \\
\hline River & 7 Rivers (France) & Gobio gobio & $\begin{array}{l}9.5- \\
4.2\end{array}$ & Sanchez et al., 2014 \\
\hline $\begin{array}{l}\text { River / } \\
\text { lake }\end{array}$ & Various (USA) & 26 species & $5-29$ & Philips and Bonner(2015) \\
\hline River & Pajeu River (Brazil) & Haplosternum littorale & 83 & J.S et al., (2016) \\
\hline
\end{tabular}

Source: (Jacqueline Santos Silva-Cavalcanti, José Diego B. Silva, Elton José de França, Maria Christina Barbosa de Araújo, Felipe Gusmão,Microplastics ingestion by a common tropical freshwater fishing resource, Environmental Pollution, Volume 221,2017,Pages 218-226,ISSN 0269-7491,https://doi.org/10.1016/j.envpol.2016.11.068.)
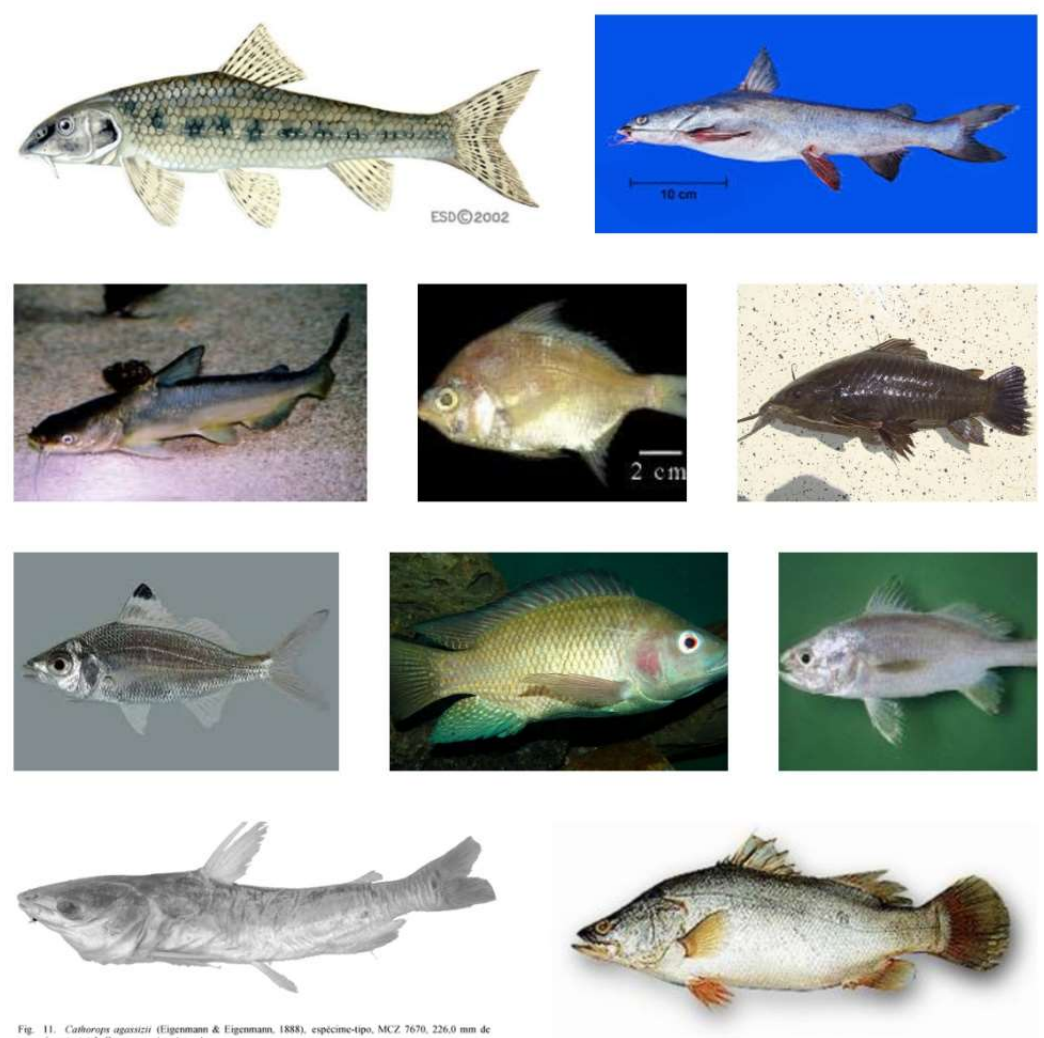
Fig: Showing some of the studied species having a considerable frequency of ingested MPs. Starting from top left in 1. Gobio gobio, 2. Sciades herbergii, 3. Cathorops spixi, 4. Diapterus rhombeus, 5.Stellifer stellifer, 6.Cathorops agassizzi and 7. Lates niloticus

\subsection{Data analysis:}

Plastic debris ingestion in fish from different freshwater habitats like rivers, estuaries, and lakes from different locations across the globe was examined by different researchers and was found that a lot of species ingest MPs. The data provided in Table 1 shows the percentage of individuals observed with plastic debris inside the gut i.e., shown as frequency percentage. Among the estuary species the frequency percent was highest in Cathorops agassizzi which were collected from Goina estuary (Brazil) in the year 2011, it had ingested debris percentage of approx $33 \%$ which is quite high. Other species like Cathorops spixi and Sciades herbergii showed the frequency equal to $18 \%$. The genus Stellifer had ingested debris frequency percentage between 6 to 9 specifically Stellifer brasilliensis (found lowest among estuary species observed) and Stellifer stellifer had 6.9 and $9.2 \%$ of ingested debris frequency respectively. Other species like Eugeress brasilianus, Eucinostomos melanopterus, and Diapterus rhombeus was found with $16.3,9,2,11.4 \%$ of frequency debris respectively.

The reports from the species thriving in Lake Victoria of African continent showed almost static frequency percentage of $20 \%$ among the studied species Lates niloticus and Oreochromis niloticus studied quite recently in the year 2016 by (Biginagwa et al., 2016). There was a high frequency of ingested debris among the species of river habitat, so far Haplosternum littorale collected from Pajeu River (Brazil) had a remarkably highest frequency percentage of $83 \%$; It is predicted to be hazardous for humans via food chain, However, it is just a hypothesis actual effects are yet to be analyzed. Other species collected from Brazos River Basin (USA) also showed the high percentage of ingested debris frequency, Leponis megalotis and Lepomis macrochirus were observed with 44 and $45 \%$ frequency respectively studied by Peters and Bratton in the year 2016. Sanchez examined Gobio gobio from 7 rivers of France in the year 2014 and found a range of frequency percentage with 9.5 to $4.2 \%$. The overall result shows that the species thriving in the rivers are mostly affected by the MPs contamination. The reason behind this could be because the river is vulnerable to various sewage discharges along with factory wastes so the chance of contamination is highest. According to the hypothesis, the biomagnifications of MPs is likely to be highest through river water species and the consumption of the infected fish with MPs can be hazardous for humans also.

\section{Effects of microplastics on fishes:}

The effects of MPs contamination on fish health are not yet fully understood. The ingestion of MPs by fishes can get accumulated in their digestive tract which can cause starvation because of the false sensation of satiation or even perforation of the gastrointestinal tract. It may also pass to predators including humans (Ferrel and Nelson, 2013; Seltenrich, 2015; Sharma and Chatterjee, 2017). Internal and digestive enzyme system may get damaged even the reproduction can because of MPs digestion (Talvite et al., 2015; Wright et al., 2013). Examples of studies are listed below.

\section{TABLE 2. SUMMARY OF MP EFFECTS:}

\begin{tabular}{lll}
\hline EFFECT & DESCRIPTION & REFERENCES \\
\hline $\begin{array}{l}\text { Increased reactive } \\
\text { oxygen species }\end{array}$ & Ingested microplastics have shown to increase & Bhattacharya et al., \\
(ROS) & $\begin{array}{l}\text { free radicals in which leads to cellular and DNA } \\
\text { damage. }\end{array}$ & 2010 \\
\hline
\end{tabular}




\section{Reduced feeding or filtering}

Immune response

Hepatic damage
Animals containing microplastic in their digestive tracts were found to eat less, resulting in lower energy levels and fat reserves
Wright et al., 2013

Wegner et al., 2012

von Moos et al., 2012

Köhler, 2010

Rochman et al., 2013

Due to metabolic stress caused by microplastics, as well as pollutants accumulating on its surface, liver damage has been found in some organisms
Lower gamete quality causes less offspring to be produced and decrease fecundity

Due to a combination of the physical and physiological effects of microplastic particles on certain individuals' fatality is increased.
Sussarellu et al., 2014

Lee et al., 2013

Mortality

1. SOURCE: (H Bouwman, K Minnaar, C Bezuidenhout, C Verster (2018) Microplastics in freshwater environments, 1 edn., Republic of South Africa: Water Research Commission.)

As MPs act as a sponge and provide surface area for various bio-organic or inorganic toxic substances; the ingestion of these adsorbed toxin containing MPs could be a serious health issue for the fishes. The negative effect of toxins on fish health was demonstrated by Rochman et al., 2013. Tiny particles of low-density polyethylene (LDPE) were exposed to environmental bay condition for consecutive three months and then fed to fishes. Soon after two months, the tissues of fish had a greater concentration of PBTs and showed signs of liver stress, glycogen depletion, fatty vacuolation and cell necrosis (Rochman et al., 2013).

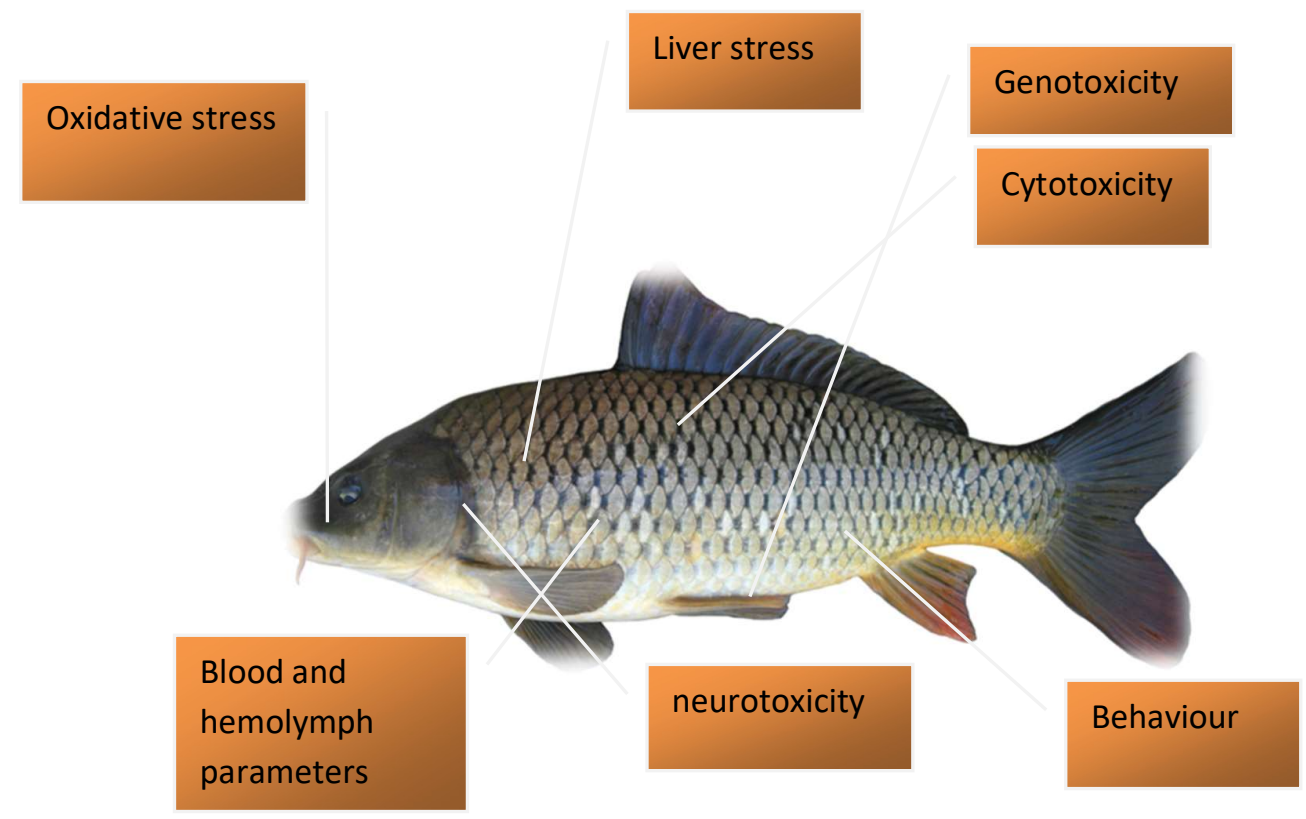

Fig showing some of the effects of MPs of freshwater fishes. 
A total of 21 studies reporting ecotoxicological effects of MPs were identified. Fishes may ingest MPs either directly or by the prey containing these particles (Desforges et al., 2014). Overall documented effects of MPs on fishes include reduction of feeding activity (Besseling et al., 2013; de Sá et al., 2015) oxidative stress(Della Torre et al., 2014) , genotoxicity (Della Torre et al., 2014) neurotoxicity (Oliveira et al., 2012-Oliveira et al., 2013; Luis et al., 2015; Ribeiro et al., 2017) growth delay ( Della Torre et al., 2014; Au et al., 2015; Redondo-Hasselerharm et al., 2018) reduction in reproductive fitness (Lee et al., 2013; Cole et al., 2015) and ultimately death (Lee et al., 2013; Au et al., 2015; Cole et al., 2015; Mazurais et al., 2015). The representation of ecotoxicological effects is shown in (fig1)

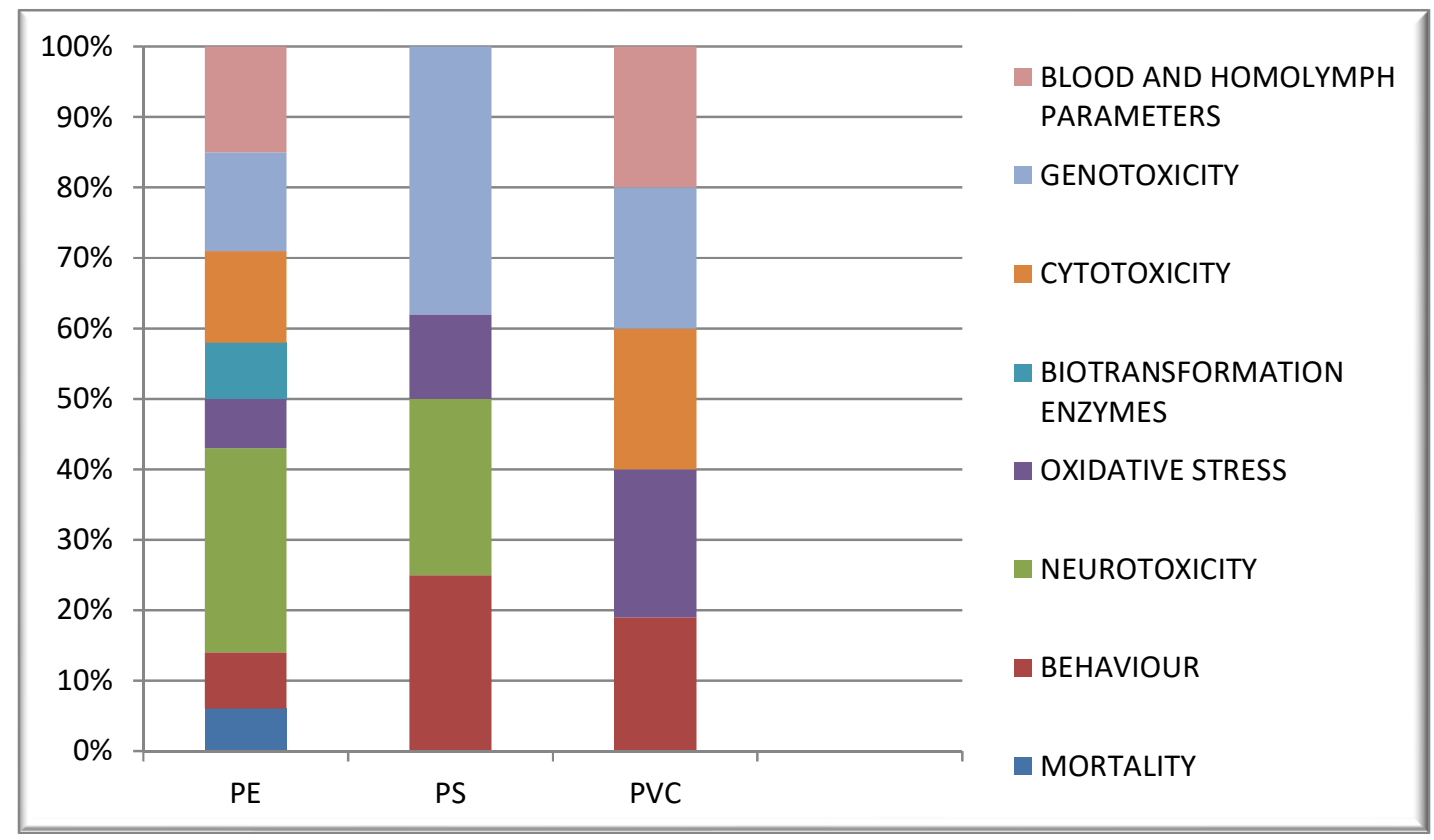

Source: (Ecotoxicological effects of MPs on fishes based on 21 studies. Studies were defined according to types of MPs and its effects. ( data from: Luís Carlos de Sá, Miguel Oliveira, Francisca Ribeiro, Thiago Lopes Rocha, Martyn Norman Futter ,Studies of the effects of microplastics on aquatic organisms: What do we know and where should we focus our efforts in the future?, Science of The Total Environment, Volume 645,)

\section{Recent global actions on MPs:-}

1. In the year 2012, Unilever decided to wipe out microplastics from all of its personal care products by the year 2015 .

2. The report of United Nations Environment Program (UNEP) in the year 2014 recommended to increase the efforts to understand the effects of MPs, its capacity to absorb and transfer persistent, toxic and bio-accumulating chemicals.

3. State of Illinois and California (USA) passed a bill to impose ban on manufacturing and selling of personal care products having microplastic beads in it, in the year 2014 and 2015 respectively.

4. The USA has banned the production of personal care products containing MPs in the year 2017 and also has decided to stop the sale of drugs containing MPs in it.

5. In the year 2018 The United Kingdom imposed a ban on the manufacture of personal care products containing microplastic beads in it. 
6. From the year 2020 countries including Sweden, Finland, France, Iceland, Ireland, Luxemberg, and Norway will ban the sale of cosmetics with MPs and have called on the EU for an EU-wide ban.

7. WHO- A $15^{\mathrm{TH}}$ March 2018 edition of the newspaper article of The Guardian reported that WHO is considering launching a health review in response to a study where MPs were found more than $90 \%$ of some of the popular packaged water brands.

\section{Conclusions:}

This paper compiled the comprehensive information about the importance of the study of MPs contamination in fresh water along with the ways of accumulation and effects on fishes. In this regard, the following topics were discussed a). Microplastics overview-types and sources, b). Methods of ingestion of MPs by fishes and c). Effects of MPs on fishes.

From the literature it can be concluded that MPs are a dormant hazard for aquatic organisms and their quantity is increasing day by day, it is the reason behind the several abnormalities in the behaviour and health of fishes. Fishes ingest MPs intentionally and sometimes unintentionally, the MPs get accumulated in the gastrointestinal tract and stomach of biota. PE, PS furthermore PVC is among the most extensively studied MPs obtained from inside the freshwater fishes. The study shows the data on the ingestion of MPs by fishes of different freshwater bodies and also provides graphs to show the effects of these accumulated particles on fishes.

Based on the investigation following conclusions can be drawn:

1. More attention is needed towards freshwater MPs studies.

2. Regulate some rules to counter the generation of MPs in water bodies.

3. There should be a ban or monitoring over the production of personal care products containing MPs, as they are one of the primary sources.

4. Toxic effects and biomagnifications of MPs through food chains need to be evaluated comprehensively.

5. Better understandings of MPs effects on humans.

6. Find out techniques to filter out MPs from wastewater in treatment plants,

7. Researchers should establish techniques of detection and filtration of MPs from water at a satisfactory level.

8. Further studies should be directed towards prevention, awareness, and reduction and counter methods.

\section{References:}

1. Anderson, P. J.,Warrack, S., Langen, V., Challis, J. K., Hanson, M.L., \& Rennie, M. D. (2017). Microplastic contamination inLake Winnipeg, Canada. Environmental Pollution, 225223-231. 10.1007/s11270-014-2184-6

2. Arthur, C., Baker, J., Bamford, H., 2009. Proceedings of the International Research Workshop on the Occurrence, Effects and Fate of Microplastic Marine Debris. In: NOAA Technical memorandum NOS-OR\&R-30, p. 49. 
3. Au, S.Y., Bruce, T.F., Bridges, W.C., Klaine, S.J., 2015. Responses of Hyalella Azteca to acute and chronic microplastic exposure. Environ. Toxicol. Chem. 34, 2564-2572

4. Barnes, D.K.A., Galgani, F., Thompson, R.C., Barlaz, M., 2009. Accumulation and fragmentation of plastic debris in global environments. Philosophical Transactions of the Royal Society B-Biological Sciences 364. 1985-1998.

5. Besseling, B.,Wegner, A., Foekema, E.M., Heuvel-Greve, M.J., Koelmans, A.A., 2013. Effects of microplastic on fitness and PCB bioaccumulation by the lugworm Arenicola marina(L.) environ. Sci. Technol. 47, 593-600.

6. Betts, K., 2008.Why small plastic particles may pose a big problem in the oceans. Environ.Sci. Technol. 42 (24) (8995-8995).

7. Bhattacharya, P., Turner, J. P., Ke, P.C., 2010. Physical adsorption of charged plastic nanoparticles affects algal photosynthesis. The Journal of Physical Chemistry 114. 1655616561.

8. Biginagwa, F.J., Mayoma, B.S., Shashoua, Y., Syberg, K., Khan, F.R., 2016. First evidence of microplastics in the African great lakes: recovery from lake Victoria nile perch and nile tilapia. J. Gt. Lakes Res. 42, 146e149. http://dx.doi.org/10.1016/i.jglr.2015.10.012

9. Browne MA, Crump P, Niven SJ, Teuten E, Tonkin A, Galloway T et al(2011) Accumulation of microplastic on shorelines worldwide: sources and sinks. Environ Sci Technol 45:9175-9179

10. Browne, M.A., 2015. In: Bergmann, M., Gutow, L., Klages, M. (Eds.), Marine Anthropogenic Litter. Springer International Publishing, Cham, pp. 229e244

11. Browne, M.A., Dissanayake, A., Galloway, T.S., Lowe, D.M., Thompson, R.C., 2008. Ingested microscopic plastic translocates to the circulatory system of themussel, Mytilus edulis (L.). Environ. Sci. Technol. 42, 5026-5031

12. Browne, M.A., Galloway, T.S., Thompson, R., 2007. Microplastic - an emerging contaminant of potential concern? Integr. Environ. Assess. Manag. 3, 559-561

13. Browne, M.A., Niven, S.J., Galloway, T.S., Rowland, S.J., Thompson, R.C., 2013. Microplastic moves pollutants and additives to worms, reducing functions linked to health and biodiversity. Curr. Biol. 23 (23), 2388-2392

14. Carson, H.S., 2013. The incidence of plastic ingestion by fishes: from the prey's perspective. Mar. Pollut. Bull. 74, 170e174

15. Cedervall, T., Hansson, L.-A., Lard, M., Frohm, B., Linse, S., 2012. Food chain transport of nanoparticles affects behaviour and fat metabolism in fish. PLOS ONE 7,e32254. http://dx.doi.org/10.1371/journal.pone.0032254 Cole, M., Lindeque, P., Halsband, C., Galloway, T.S., 2011. Microplastics as contaminantsin the marine environment: a review. Mar. Pollut. Bull. 62 (12),2588e2597

16. Cole, M., Lindeque, P., Fileman, E., Halsband, C., Galloway, T.S., 2015. The impact of polystyrenemicroplastics on feeding, function and fecundity in the marine copepodCalanus helgolandicus. Environ. Sci. Technol. 49, 1130-1137

17. Cristóbal Espinosa M. Ángeles Esteba Alberto Cuestz Sonia Soloneski Marcelo L. Larramendy 2016-10-26 2016 Microplastics in Aquatic Environments and Their Toxicological Implications for Fish Toxicology Ch. 6https://doi.org/10.5772/64815 10.5772/64815 978-953-51-2717-8 IntechOpen Rijeka 2018-09-26

18. Dantas, D.V., Barletta, M., Da Costa, M.F., 2012. The seasonal and spatial patterns of ingestion of polyfilament nylon fragments by estuarine drums (Sciaenidae).Environ. Sci. Pollut. Res. 19, 600e606.

19. de Araújo, Felipe Gusmão,Microplastics ingestion by a common tropical freshwater fishing resource,Environmental Pollution,Volume 221,2017,Pages 218-226,ISSN 02697491,https://doi.org/10.1016/j.envpol.2016.11.068

20. de Sá, L.C., Luís, L.G., Guilhermino, L., 2015. Effects of microplastics on juveniles of the common goby (Pomatoschistus microps): confusion with prey, reduction of the 
predatoryperformance and efficiency, and possible influence of developmental conditions.Environ. Pollut. 196, 359-362

21. Della Torre, C., Bergami, E., Salvati, A., Faleri, C., Cirino, P., Dawson, K.A., Corsi, I., 2014. Accumulation and embryotoxicity of polystyrene nanoparticles at early stage of development of sea urchin embryos Paracentrotus lividus. Environ. Sci. Technol. 48 (20),12302-12311

22. Desforges, J.P.W., Galbraith, M., Dangerfield, N., Ross, P.S., 2014. Widespread distribution of microplastics in subsurface seawater in the NE Pacific Ocean. Mar. Pollut. Bull.79, 94-99

23. Desforges, J.P.W., Galbraith,M., Ross, P.S., 2015. Ingestion of microplastics by zooplankton in the Northeast Pacific Ocean. Arch. Environ. Contam. Toxicol. 69, 320-330

24. Duis, Karen, and Anja Coors. "Microplastics in the Aquatic and Terrestrial Environment: Sources (with a Specific Focus on Personal Care Products), Fate and Effects." Environmental Sciences Europe 28, no. 1 (January 6, 2016). doi:10.1186/s12302-015-0069-y.

25. EPA, 2014. Plastics Common Wastes \& Materials US EPA (WWW Document)

26. Farrell, P., \& Nelson, K. (2013). Trophic level transfer ofmicroplastic: Mytilus edulis (L.) to Carcinus maenas (L.) Environmental Pollution, 177, 1-3.

27. Fendall, Lisa S., and Mary A. Sewell. "Contributing to Marine Pollution by Washing YourFace:Microplastics in Facial Cleansers." Marine Pollution Bulletin 58, no. 8 (August 2009): 1225-1228. doi:10.1016/j.marpolbul.2009.04.025

28. H Bouwman, K Minnaar, C Bezuidenhout, C Verster (2018) Microplastics in freshwater environments, 1 edn., Republic of South Africa: Water Research Commission.p 5-22

29. Habib D, Locke DC, Cannone $\sqcup$ (1998) Synthetic fibers as indicators of municipal sewage sludge,sludge products, and sewage treatment plant effluents. Water Air Soil Pollut 103:1-8

30. Hidalgo-Ruz, V., Gutow, L., Thompson, R.C., Thiel, M., 2012. Microplastics in the marineenvironment: a review of the methods used for identification and quantification. Environ. Sci. Technol. 46 (6), 3060-3075 in the Northeast Pacific Ocean. Arch. Environ. Contam. Toxicol. 69, 320-330

31. Ivar do Sul, J.A., Costa, M.F., 2007. Marine debris review for Latin America and the wider Caribbean region: from the 1970 s until now, and where do we go from here? Mar. Pollut. Bull. 54, 1087e1104

32. Jacqueline Santos Silva-Cavalcanti, José Diego B. Silva, Elton José de França, Maria Christina Barbosa de Araújo, Felipe Gusmão,Microplastics ingestion by a common tropical freshwater fishing resource,Environmental Pollution,Volume 221,2017, Pages 218-226, ISSN 02697491,https://doi.org/10.1016/j.envpol.2016.11.068

33. Jingyi Li, Huihui Liu, J. Paul Chen, Microplastics in freshwater systems: A review on occurrence, environmental effects, and methods for microplastics detection, Water Research,Volume 137,2018,Pages 362-374,ISSN 00431354,https://doi.org/10.1016/j.watres.2017.12.056

34. Khalida Jabeen, Lei Su, Jiana Li, Dongqi Yang, Chunfu Tong, Jingli Mu, Huahong Shi,Microplastics and mesoplastics in fish from coastal and fresh waters of China,Environmental Pollution,Volume 221,2017,Pages 141-149,ISSN 02697491,https://doi.org/10.1016/j.envpol.2016.11.055

35. Köhler, A., 2010. Cellular fate of organic compounds in marine invertebrates. Comparative Biochemistry and Physiology-Part A: Molecular \& Integrative Physiology 157 (Supplement) 8-11.

36. L€onnstedt, O.M., Ekl€ov, P., 2016. Environmentally relevant concentrations of microplastic particles influence larval fish ecology. Science 352,1213e1216.http://dx.doi.org/10.1126/science.aad8828

37. Laist, D.W., 1997. Impacts of Marine Debris: Entanglement of Marine Life in Marine Debris Including a Comprehensive List of Species with Entanglement and Ingestion Records, in: Marine Debris. Springer, pp. 99e139 
38. Lechner, A., Keckeis, H., Lumesberger-Loisl, F., Zens, B., Krusch, R., Tritthart, M., Glas, M.,Schludermann, E., 2014. The Danube so colourful: a potpourri of plastic litter outnumbers fish larvae in Europe's second largest river. Environ. Pollut. http://dx.doi.org/10.1016/j.envpol.2014.02.006

39. Lee, K.W., Shim, W.J., Kwon, O.Y., Kang, J.H., 2013. Size-dependent effects of micro polystyrene particles in the marine copepod Tigriopus japonicas. Environ. Sci. Technol.47 (19), 11278-11283

40. Lithner, D., Larsson, A., Dave, G., 2011. Environmental and health hazard ranking and assessment of plastic polymers based on chemical composition. Sci. Total Environ.409, 3309-3324. http://dx.doi.org/10.1016/j.scitotenv.2011.04.038

41. Luís Carlos de Sá, Miguel Oliveira, Francisca Ribeiro, Thiago Lopes Rocha, Martyn Norman Futter,Studies of the effects of microplastics on aquatic organisms: What do we know and where should we focus our efforts in the future?,Science of The Total Environment, Volume 645,2018 ,Pages 1029-1039,ISSN 00489697,https://doi.org/10.1016/j.scitotenv.2018.07.207.

42. Luis, L., Ferreira, P., Fonte, E., Oliveira, M., Guilhermino, L., 2015. Does the presence of microplastics influence the acute toxicity of chromium(VI) to early juveniles of the common goby (Pomatoschistus microps)? A study with juveniles from two wild estuarine populations. Aquat. Toxicol. 164, 163-174

43. Lusher, A.L., McHugh,M., Thompson, R.C., 2013. Occurrence ofmicroplastics in the gastrointestinaltract of pelagic and demersal fish from the English Channel. Mar. Pollut.Bull. 67, 9499

44. Mattsson, K., Ekvall, M.T., Hansson, L.-A., Linse, S., Malmendal, A., Cedervall, T., 2015.Altered behavior, physiology, and metabolism in fish exposed to polystyrenenanoparticles. Environ. Sci. Technol. 49, 553e561. http://dx.doi.org/10.1021/es5053655

45. Mazurais, D., Emande, B., Quazuguel, P., Severe, A., Huelvan, C., Madec, L., Mouchel, O.,Soudant, P., Robbens, J., Huvet, A., Zambonino-Indante, J., 2015. Evaluation of the impactof polyethylene microbeads ingestion in European sea bass (Dicentrarchus labrax) larvae. Mar. Environ. Res. 112 (Part A), 78-85. of microplastics in subsurface seawater in the NE Pacific Ocean. Mar. Pollut. Bull.79, 94-99.

46. Oliveira, M., Ribeiro, A., Guilhermino, L., 2012. Effects of short-term exposure to microplastics and pyrene on Pomatoschistus microps (Teleostei, Gobiidae). Comp. Biochem. Physiol. A Mol. Integr. Physiol. 163 (S20-S20).

47. Oliveira, M., Ribeiro, A., Hylland, K., Guilhermino, L., 2013. Single and combined effects of microplastics and pyrene on juveniles ( $0+$ group) of the common goby Pomatoschistus microps (teleostei: gobiidae). Ecol. Indic. 34, 641-647

48. Peters, C.A., Bratton, S.P., 2016. Urbanization is a major influence on microplastic ingestion by sunfish in the Brazos River Basin, Central Texas, USA. Environ.Pollut. 210, 380e387. http://dx.doi.org/10.1016/i.envpol.2016.01.018.

49. Peters, C.A., Bratton, S.P., 2016. Urbanization is a major influence on microplastic ingestion by sunfish in the Brazos River Basin, Central Texas, USA. Environ.Pollut. 210, 380e387. http://dx.doi.org/10.1016/j.envpol.2016.01.018.

50. Phillips, M.B., Bonner, T.H., 2015. Occurrence and amount of microplastic ingested by fishes in watersheds of the Gulf of Mexico.Mar.Pollut.Bull.100,264e269.http://dx.doi.org/10.1016/j.marpolbul.2015.08.041

51. Phillips, Melissa B., and Timothy H. Bonner. "Occurrence and Amount of Microplastic Ingested by Fishes in Watersheds of the Gulf of Mexico." Marine Pollution Bulletin 100, no. 1 (November 2015): 264-269. doi:10.1016/j.marpolbul.2015.08.041 
52. Plastic EuropeRedondo-Hasselerharm, P.E., Falahudin, D., Peeters, E.T.H.M., Koelmans, A.A., 2018. Microplastic effect thresholds for freshwater benthic macroinvertebrates. Environ. Sci. Technol. 52 (4), 2278-2286.

53. Plastics Europe, 2017. Plastics - The Facts 2017. Plastics Europe, Brussels (44 pp).

54. PlasticsEurope, 2013. Plastics - the Facts 2013: an Analysis of European Latest Plastics

55. Possatto, F.E., Barletta, M., Costa, M.F., Ivar do Sul, J.A., Dantas, D.V., 2011. Plasticdebris ingestion by marine catfish: an unexpected fisheries impact. Mar. Pollut.Bull. 62, 1098e1102. http://dx.doi.org/10.1016/j.marpolbul.2011.01.036. Production, Demand and Waste Data, Octubre 2013.

56. Ramos, J.A., Barletta, M., Costa, M.F., 2012. Ingestion of nylon threads by Gerreidae while using a tropical estuary as foraging grounds. Aquat. Biol. 17, $29 \mathrm{e} 34$.

57. Ribeiro, F., Garcia, A.R., Pereira, B.P., Fonseca, M., Mestre, N.C., Fonseca, T.G., IlharcoL.M.,Bebianno, M.J., 2017. Microplastics effects in Scrobicularia plana. Mar. Pollut. Bull.122 (1-2), 379-391

58. Rochman, C.M., 2013. Plastics and priority pollutants: a multiple stressor in aquatic habitats. Environ. Sci. Technol. 47, 2439-2440

59. Rochman, C.M., Hoh, E., Kurobe, T., Teh, S.J., 2013. Ingested plastic transfers hazardous chemicals to fish and induces hepatic stress. Sci. Rep. 3, 3263 http://dx.doi.org/10.1038/srep03263

60. Rummel, C.D., Adolfsson-Erici, M., Jahnke, A., MacLeod, M., 2016. No measurable“cleaning" of polychlorinated biphenyls from Rainbow Trout in a 9 week depurationstudy with dietary exposure to $40 \%$ polyethylene microspheres. Environ.

61. Ryan, P.G., Moore, C.J., van Franeker, J.A., Moloney, C.L., 2009. Monitoring the abundance of plastic debris in the marine environment. Philos. Trans. R. Soc. Lond. B Biol. Sci. 364,1999e2012Sci. Process. Impacts 18, 788e795. http://dx.doi.org/10.1039/C6EM00234J.

62. Sanchez, W., Bender, C., Porcher, J.-M., 2014. Wild gudgeons (Gobio gobio) from French rivers are contaminated by microplastics: preliminary study and first evidence. Environ. Res. 128, 98e100. http://dx.doi.org/10.1016/i.envres.2013.11.004.

63. Seltenrich, N., 2015. New link in the food chain? Marine plastic pollution and seafood safety. Environmental Health Perspectives 123. A35-A41

64. Shahabaldin Rezania, Junboum Park, Mohd Fadhil Md Din, Shazwin Mat Taib, Amirreza Talaiekhozani, Krishna Kumar Yadav, Hesam Kamyab,Microplastics pollution in different aquatic environments and biota: A review of recent studies,Marine Pollution Bulletin,Volume 133,2018, Pages 191-208,ISSN 0025326X,https://doi.org/10.1016/j.marpolbul.2018.05.022

65. Sharma, S., Chatterjee, S., 2017. Microplastic pollution, a threat to marine ecosystem and human health: a short review. Environmental Science and Pollution Research 24. 2153021547

66. Sigler, M., 2014. The effects of plastic pollution on aquatic wildlife: current situations and future solutions. Water. Air. Soil Pollut. 225, 2184. http://dx.doi.org/

67. Su, L., Xue, Y., Li, L., Yang, D., Kolandhasamy, P., Li, D., Shi, H., 2016. Microplastics in Taihu Lake, China. Environmetnal Pollution 216. 711-719.

68. Sussarellu, R., Soudant, P., Lambert, C., Fabioux, C., Corporeau, C., Laot, C., et al., 2014. Microplastics: effects on oyster physiology and reproduction. Platform presentation, International workshop on fate and impact of microplastics in marine ecosystems (MICRO2014), 13-15 January 2014. Plouzane (France).

69. Talvitie, J., Heinonen, M., Pääkkönen, J-P., Vathera, E., Setalälä, O., Vahala, R., 2015. Do wastewater treatment plants act as a potential point source of microplastics? Preliminary study in the coastal Gulf of Finland, Baltic Sea. Water Science \& Technology 72. 1495-1504 
70. Thompson, R.C., Moore, C.J., VomSaal, F.S., Swan, S.H., 2009. Plastics, the environment andhuman health: current consensus and future trends. Philos. Trans. R. Soc. Lond. Ser. B Biol. Sci. 364, 2153-2166

71. Thompson, R.C., Olsen, Y., Mitchell, R.P., Davis, A., Rowland, S.J., John, A.W.G., McDonigle, D., Rusell, A.E., 2004. Lost at sea: Where is all the plastic? Science 304. 838. 220-224

72. Van Cauwenberghe, L., Devriese, L., Galgani, F., Robbens, J., Janssen, C.R., 2015. Microplastics in sediments: A review of techniques, occurrence and effects. Marine Environmental Research 111. 5 -17

73. Vendel, A.L. et al. "Widespread Microplastic Ingestion by Fish Assemblages in Tropical Estuaries Subjected to Anthropogenic Pressures." Marine Pollution Bulletin 117.1-2 (2017): 448-455

74. von Moos, N.; Burkhardt-Holm, P., Kohler, A., 2012. Uptake and effects of microplastics on cells and tissue of the blue mussel Mytilus edulis L. after an experimental exposure. Environmental Science \& Technology 46. 11327-11335.

75. Wagner, M., Lambert, S., 2018. Freshwater microplastics. Emerging environmental contaminants? The Handbook of Environmental Chemistry Vol 58. Springer Open, Cham, Switzerland

76. Wagner, M., Scherer, C., Alvarez-Mu〜noz, D., Brennholt, N., Bourrain, X., Buchinger, S.,Fries, E., Grosbois, C., Klasmeier, J., Marti, T., Rodriguez-Mozaz, S., Urbatzka, R.,Vethaak, A.D., Winther-Nielsen, M., Reifferscheid, G., 2014. Microplastics infreshwater ecosystems: what we know and what we need to know. Environ. Sci.Eur. 26, 12. http://dx.doi.org/10.1186/s12302-014-0012-7.

77. Wright, S.L., Rowe, D., Thompson, R.C., Galloway, T.S., 2013. Microplastic ingestion decreases energy reserves in marine worms. Current Biology 23(23) R1031-R1033.

78. Wright, S.L., Rowe, D., Thompson, R.C., Galloway, T.S., 2013. Microplastic ingestion decreases energy reserves in marine worms. Current Biology 23(23) R1031-R1033.

79. Wright, S.L., Thompson, R.C., Galloway, T.S., 2013. The physical impacts of microplastics on marine organisms: A review. Environmental Pollution 178. 483-492.

80. Yu, Yue Zhou, Dongren Li, Zhanming Zhu, Cheng 2018 2018/04/17 Advancement and Challenges of Microplastic Pollution in the Aquatic Environment: a Review Water, Air, \& Soil Pollution 1402295 1573-2932 https://doi.org/10.1007/s11270-018-3788-z 10.1007/s11270018-3788-zYu2018

81. Zhao, S., Zhu, L., Li, D., 2015. Microplastic in three urban estuaries, China. Environ.Pollut. 206, 597-60 